\title{
A Novel Approach to the Synthesis of
}

\author{
DNA and RNA Lariats
}

\author{
Debbie Mitra and Masad J. Damha*
}

Department of Chemistry, Otto Maass Chemistry Building, McGill University, 801 Sherbrooke Street

West, Montreal, QC, H3A 2K6, Canada

*To whom correspondence should be addressed. Phone: (514)398-7552. Fax: (514)398-3797.

Email: masad.damha@mcgill.ca

\section{Content}

General Methods: $\quad$ S2

$\begin{array}{ll}\text { Figure S1: Thermal Denaturation of 1c and 2c. } & \text { S3 }\end{array}$

$\begin{array}{ll}\text { Figure S2: Circular Dichorism of 1c and 2c. } & \text { S4 }\end{array}$

$\begin{array}{ll}\text { Figure S3: Thermal denaturation and circular dichroism of 8c. } & \text { S4 }\end{array}$

Figure S4: $20 \%$ PAGE, 8.3 M, CNBr chemical ligations of $\mathbf{1 b}$ and $\mathbf{2 b}$; template variation. $\quad$ S5

Figure S5: MALDI-TOFF MS analysis of RNA lariat, $8 c . \quad$ S5/S6

$\begin{array}{ll}\text { Figure S6: Anion-exchange HPLC of crude EDC coupling of 8a:10. } & \text { S7 }\end{array}$

$\begin{array}{ll}\text { Figure S7: } 20 \text { \% PAGE, 8.3 M Urea. EDC Control Experiment. } & \text { S7 }\end{array}$

Figure S8: Thermal denaturation and circular dichroism characterization of parallel orientation. S8

Figure S9: Thermal denaturation and circular dichroism characterization of control duplexes. $\quad$ S8

$\begin{array}{ll}\text { Figure S10: Native PAGE of parallel orientation. } & \text { S10 }\end{array}$

$\begin{array}{ll}\text { Figure S11: RNase H digestion of parallel duplex assembly. } & \text { S11 }\end{array}$ 
General Methods. All solvents, coupling reagents and phosphoramidites for DNA and RNA solid phase synthesis, conducted on a DNA synthesizer, were purchased from Chemgenes. Introduction of a 5'-phosphate, through phosphoramidite chemistry, at the terminus of an oligonucleotide was incorporated via a 5'-phosphate-ON (2-[2-(4,4'-dimethoxytrityloxy)ethylsulfonyl]ethyl-( $\beta$-cyanoethyl)( $N, N$-diisopropyl) phosphoramidite) reagent, catalog number CLP-1544 (Chemegenes). The coupling efficiency was monitored by standard detritylation where the cationic dimethoxytrityl groups are UV active. Sephadex G-25 is purchased from Amersham Biosciences. Characterization, purification and isolation of all reactions were acquired by PAGE (16-24\%, 8.3 M urea) and desalted using Sephadex G25 columns. Samples were heated to $95^{\circ} \mathrm{C}$ in $10 \mu \mathrm{L}$ of deionized formamide as it was necessary to fully denature the oligonucleotides prior to loading. The reactions were visualized by UV-shadowing or STAINS-ALL (prepared by commercial protocol). A MALDI-TOF-MS was conducted in the negative mode with matrix, 6-aza-2-thiothymine in combination with co-matrices spermine and fucose, prepared by literature procedure. ${ }^{1}$ Thermal denaturation studies, monitored at $260 \mathrm{~nm}$ at increments of $0.3 \%$ min in a $1 \mathrm{~cm}$ path length cell, were conducted (repeated at least twice). The melting temperatures $\left(\mathrm{T}_{\mathrm{m}}\right)$ were calculated as the first derivative of the thermal melting profile (absorbance vs temperature). Circular dichroism (CD) spectra were obtained on a spectropolarimeter at $4{ }^{\circ} \mathrm{C}$ in the range of $200-330$ $\mathrm{nm}$ and also conducted twice over. Both thermal melting and CD samples were prepared in stoichiometric amounts of appropriate oligonucleotide strands at 2-4 $\mu \mathrm{M}$ in $10 \mathrm{mM}$ Tris- $\mathrm{HCl}, \mathrm{pH} 7.5$, and $10 \mathrm{mM} \mathrm{NaCl}$ buffer. Annealing protocol of all $\mathrm{T}_{\mathrm{m}}$ and $\mathrm{CD}$ samples required heating to $95{ }^{\circ} \mathrm{C}$ for 10 minutes and slowly cooling to $4{ }^{\circ} \mathrm{C}$, and maintained for $12-24 \mathrm{~h}$. The $\mathrm{CD}$ theoretical controls of the A and B conformation were obtained from N. Berova, K. Nakanishi, R.W. Woody, Circular Dichroism: Principles and Applications, 2nd Ed., Wiley-VCH, Weinheim, 2000. 
a)

DNA Lariat 1c
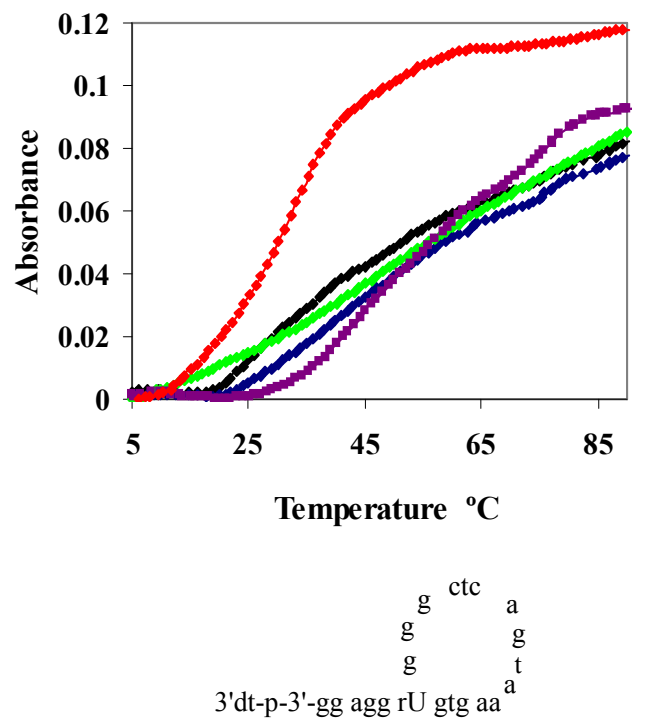

$\mathrm{T}_{\mathrm{m}}$ ssON(rU):RNA (1a:4): $48,70{ }^{\circ} \mathrm{C}$

$\mathrm{T}_{\mathrm{m}}$ DNA lariat(rU):RNA (1c:4): $31^{\circ} \mathrm{C}$

$\mathrm{T}_{\mathrm{m}}$ duplex control (11b:10): $42^{\circ} \mathrm{C}$ b)
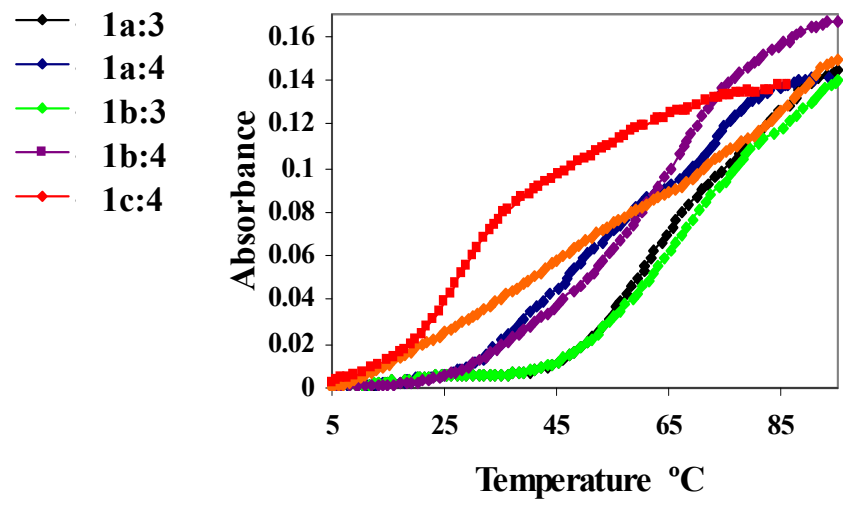

$\rightarrow \quad 2 \mathrm{a}: 5$

$\rightarrow \quad 2 \mathrm{a}: 6$

$\rightarrow 2 \mathrm{~b}: 5$

$\rightarrow \quad 2 \mathrm{~b}: 6$

$\rightarrow \quad 2 b: 7$

$\multimap 2 \mathrm{c}: 6$

Figure S1. Thermal denaturation experiments of pre- and post-ligation duplexes at 2-4 $\mu \mathrm{M}$ in $10 \mathrm{mM}$ Tris-HCl, $\mathrm{pH}$ 7.5, $10 \mathrm{mM} \mathrm{NaCl}$ buffer. Sequences of oligonucleotides are given in Table 1. 
a)

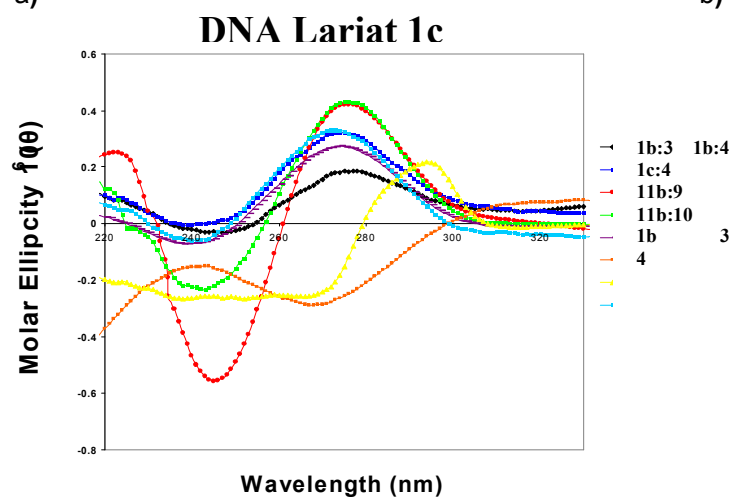

Wavelength $(\mathrm{nm})$

b)

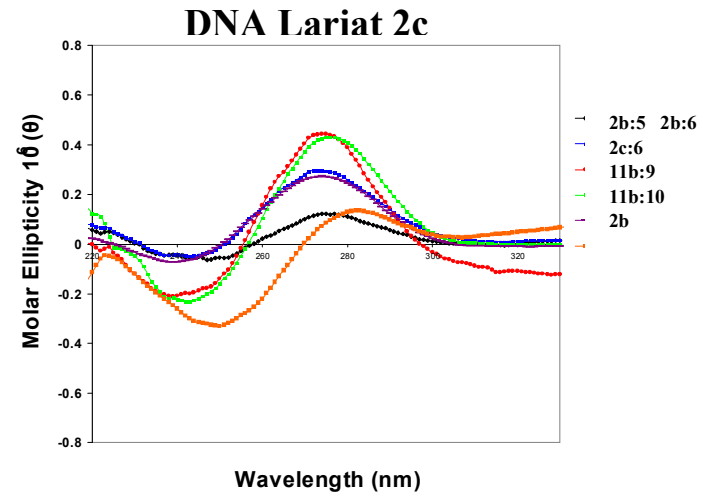

Figure S2. Circular dichroism spectra of ssON, lariat DNA and their complexes. Strand concentration of 2-4 $\mu \mathrm{M}$ in $10 \mathrm{mM}$ Tris- $\mathrm{HCl}, \mathrm{pH}$ 7.5, $10 \mathrm{mM} \mathrm{NaCl}$ buffer.

a)

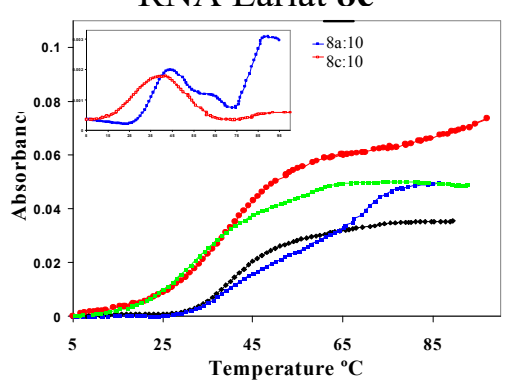

b)

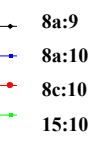

- 8a:9

- $8 \mathrm{c}: 10$ $15: 10$ 3'C AGG AGG rU GTG AA
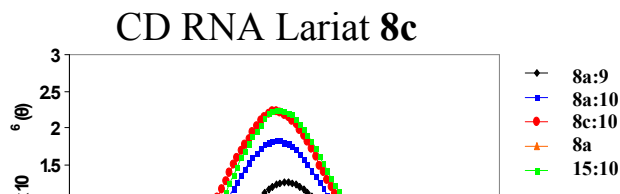

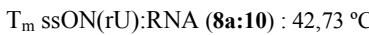

$\mathrm{T}_{\mathrm{m}}$ RNA lariat(rU):RNA $(\mathbf{8 c}: \mathbf{1 0}): 39^{\circ} \mathrm{C}$

$\mathrm{T}_{\mathrm{m}}$ RNA parallel control (15:10): $31^{\circ} \mathrm{C}$

Figure S3. Thermal denaturation and CD spectra of (a) pre-lariat RNA and (b) lariat RNA. All samples at a strand concentration of $2-4 \mu \mathrm{M}$ in $10 \mathrm{mM}$ Tris- $\mathrm{HCl}, 10 \mathrm{mM} \mathrm{NaCl}, \mathrm{pH} 7.5$ buffer. 


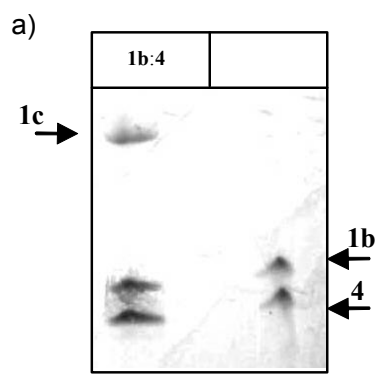

b)

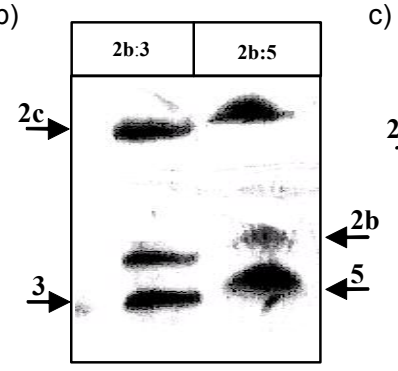

c)

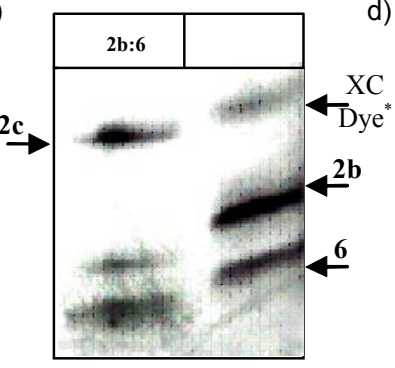

d)

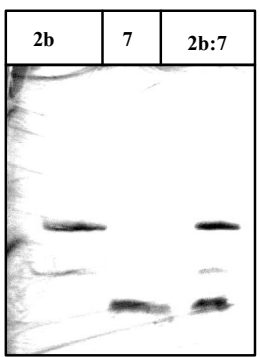

Figure S4. $20 \%$ PAGE, 8.3 M, CNBr chemical ligations of $\mathbf{1 b}$ and $\mathbf{2 b}$; template variation. a) synthesis of rU DNA lariat 1c through chemical ligation of 1b:4 (30\% yield). Synthesis of rA DNA lariat 2c. b) chemical ligation of $\mathbf{2 b : 3}$ and $\mathbf{2 b : 5}(64,73 \%$ yield respectively). c) Chemical ligation of $\mathbf{2 b : 6}$ ( $81 \%$ yield). d) Chemical ligation of $\mathbf{2 b}: \mathbf{7}$, no reaction observed.*$\mathrm{XC}$ Dye, is xylene cyanol tracking dye migrating at a rate similar to a 28 mer oligonucleotide in a $20 \%$ PAGE.

a) Cyclic RNA lariat, 8c.

Kratos Kompact MALDI 3 V5.2.4: - Linear High Power: 85

$\%$ Int. $\quad 100 \%=556 \mathrm{mV}$ Profiles $1-13$ : Centroid

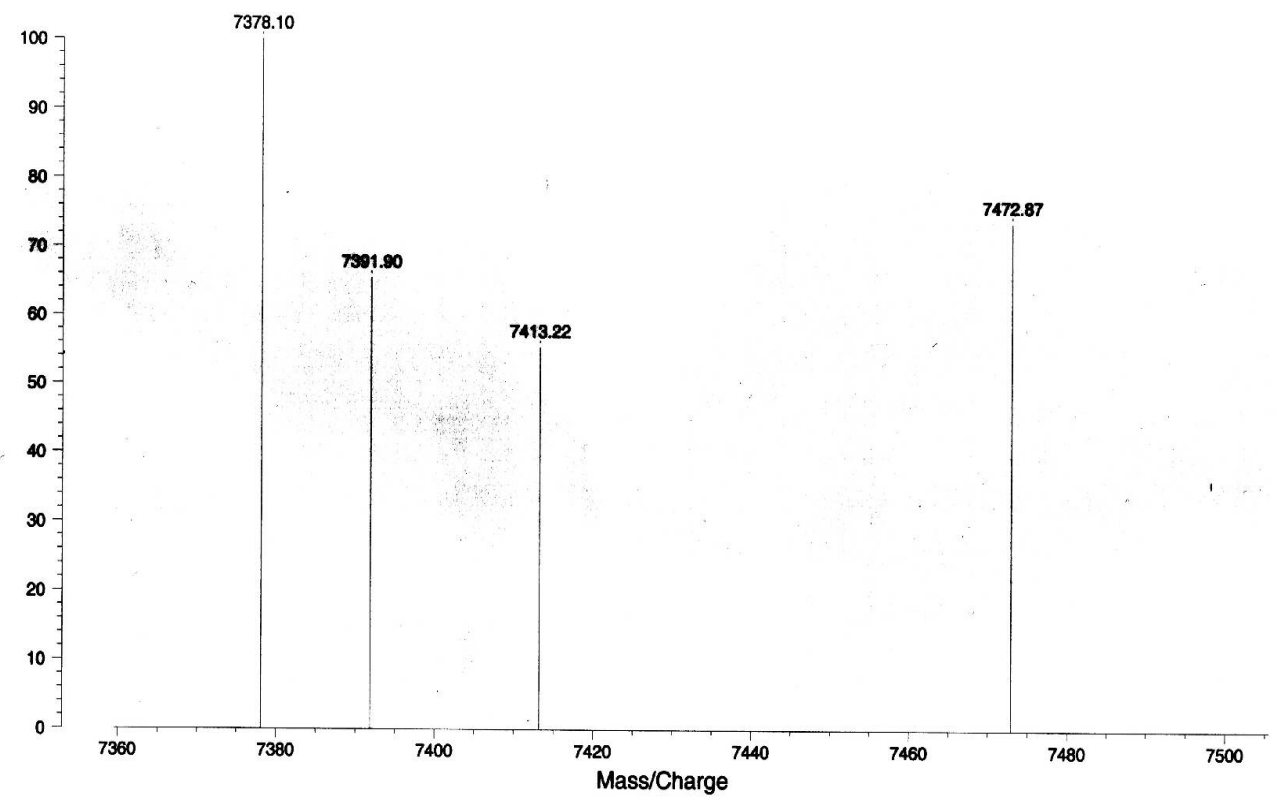


b) Nicked precursor linear strands, $\mathbf{8} \mathbf{a}$

Kratos Kompact MALDI 3 V5.2.4: - Linear High Power: 101

\%Int. $\quad 100 \%=3 \mathrm{mV}[\mathrm{sum}=26 \mathrm{mV}$ ] Profiles $19-26$ Smooth Av 8
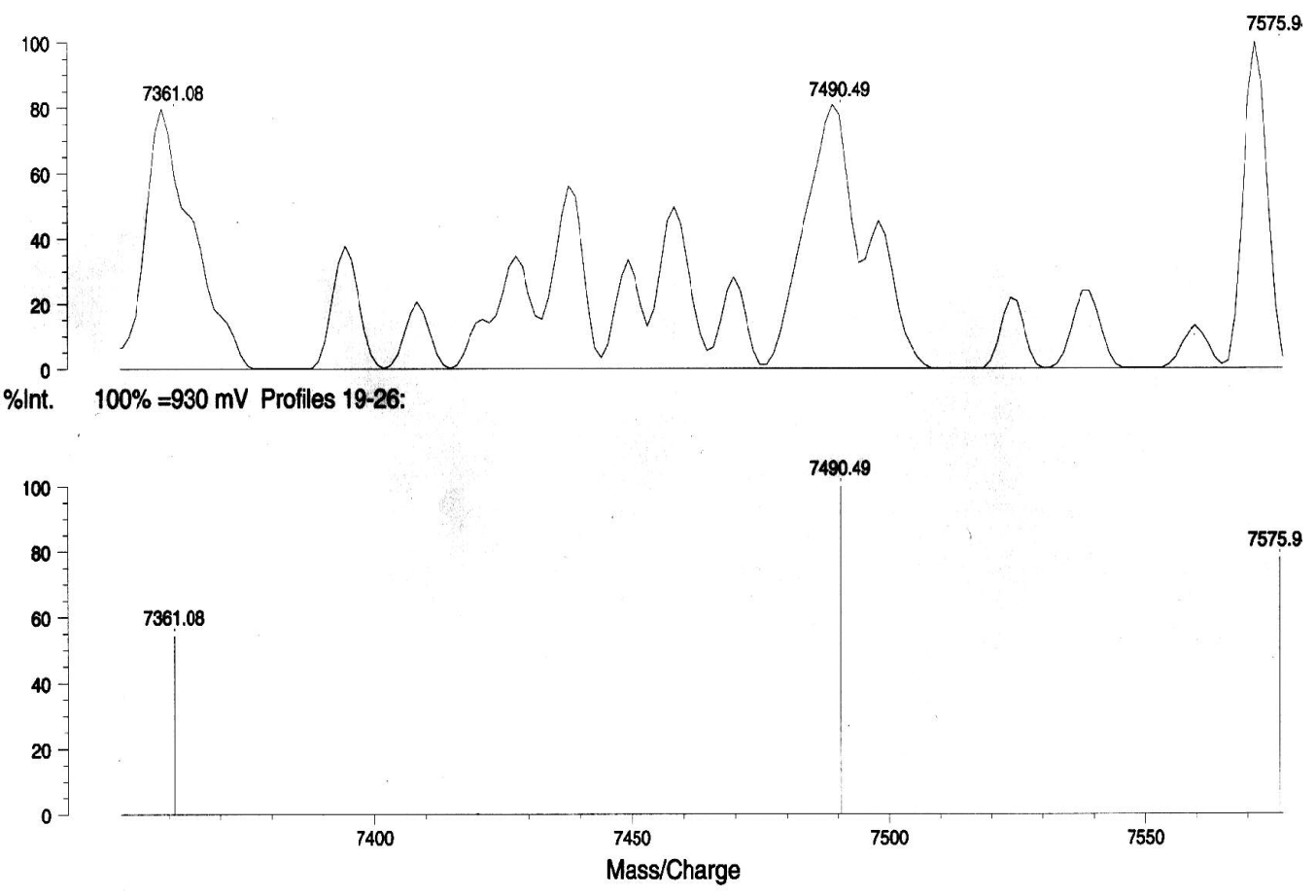

c) Mixed analysis of nicked precursor strands, 8a and cyclic RNA lariat, 8c.

Kratos Kompact MALDI 3 V5.2.4: - Linear High Power: 106

\%Int. $\quad 100 \%=4 \mathrm{mV}[\mathrm{sum}=37 \mathrm{mV}]$ Profiles $1-8$ Smooth Av 8
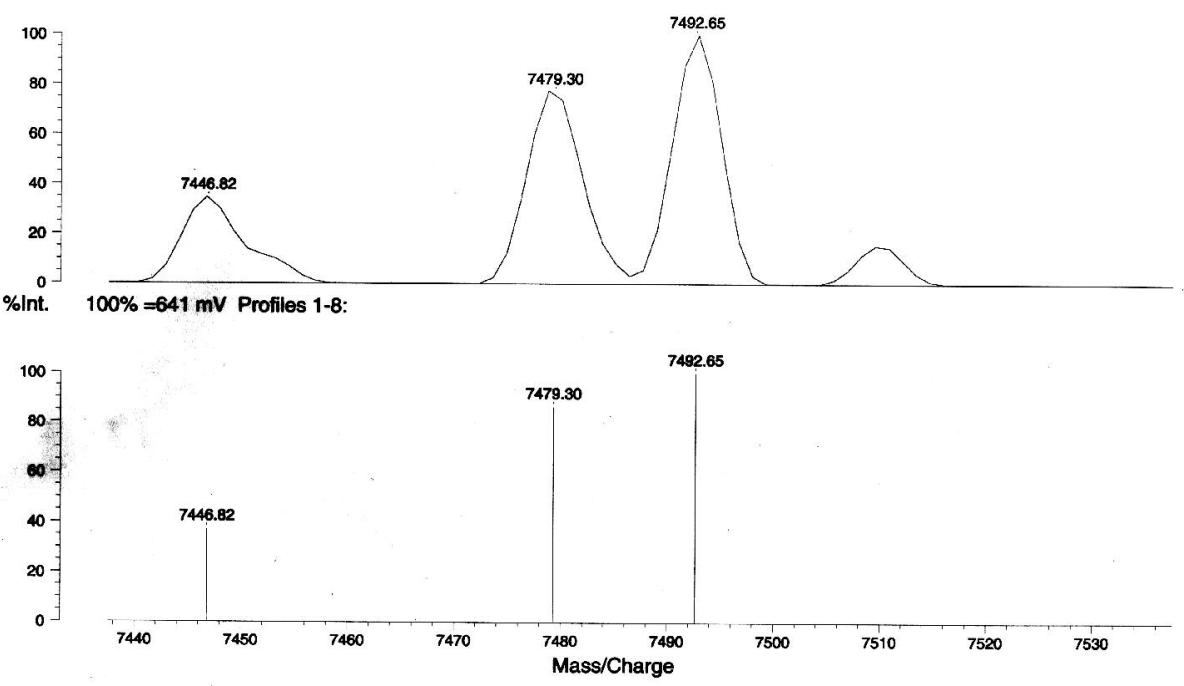

Figure S5. MALDI-TOFF MS analysis of RNA lariat, 8c. a) Represents cyclic lariat product 8c. b) linear precursor 8a. c) Mixture of the linear precursor and lariat product, $\mathbf{8 a}+\mathbf{8 c}$. 


\section{EDC Coupling $8 \mathrm{a}+10,0.5 \mathrm{M}, 7$ days}

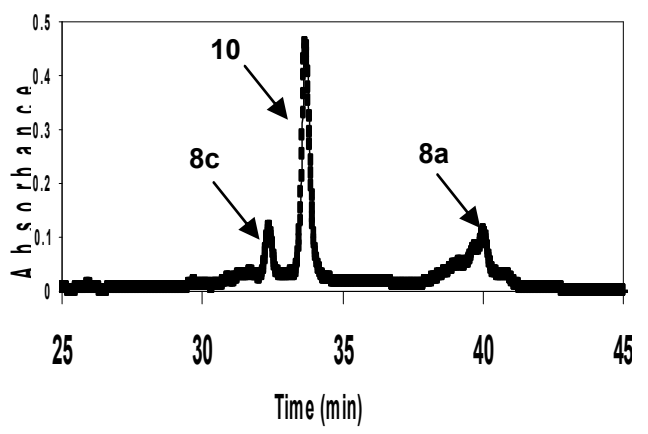

Figure S6. Anion-exchange HPLC of crude EDC coupling of 8a:10 under optimal conditions, $0.5 \mathrm{M}, 22$ $\mu \mathrm{M} 8 \mathbf{a}$, and 6 day coupling.

\section{Control Reaction}

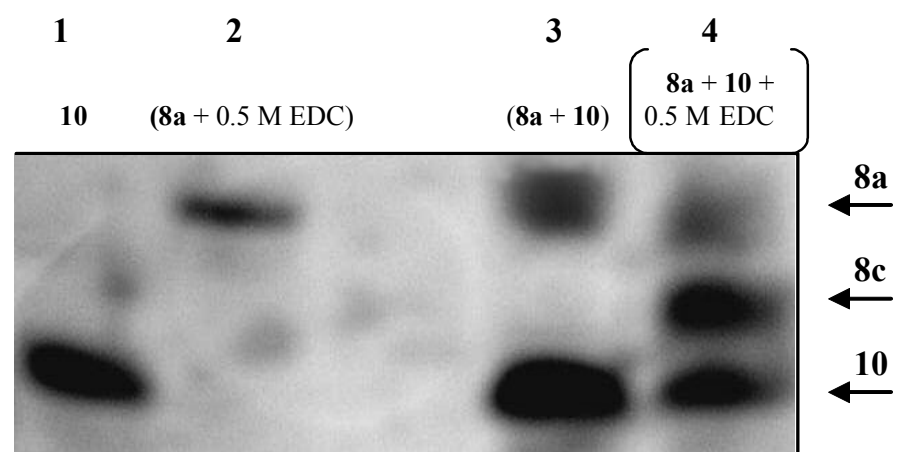

Figure \$7. 20 \% PAGE, 8.3 M Urea. Control Experiment. Lane 1. Control RNA unidirectional template 10 . Lane 2. reaction with absence of template $\mathbf{8 a}+$ EDC where no side reactions are observed. Lane $3 . \mathbf{8 a}+\mathbf{1 0}$ coupling reaction conducted (ie. hybridization protocol) in the absence of EDC condensing reagent. Lane $4 . \mathbf{8 a}+\mathbf{1 0}$ in the presence of EDC. Standard reaction conditions of $0.5 \mathrm{M} \mathrm{EDC}, 22 \mu \mathrm{M} 8 \mathrm{8a}, 6$ days. 


\section{Characterization of Control Duplexes}

a)

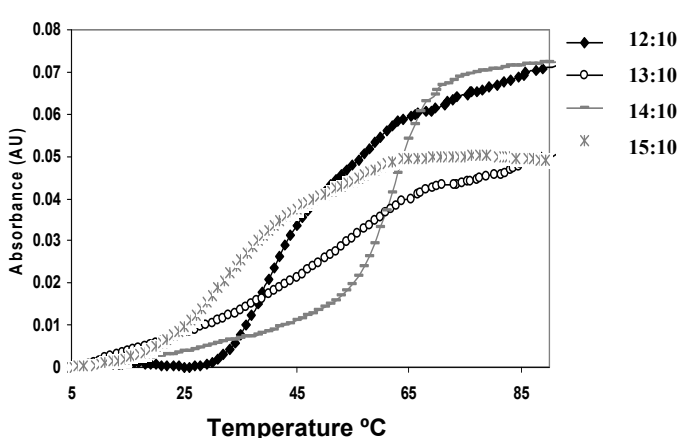

b)

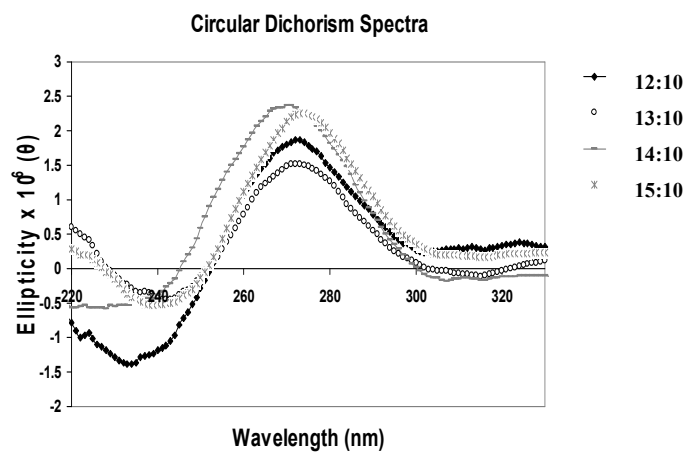

Figure S8. A study on parallel orientation upon duplex formation a) Thermal Denaturation Experiments of control duplexes 12, 13, 14, 15:10. b) Circular dichorism spectra of control duplexes 12, 13, 14, 15:10. For all samples experiments were conducted in a concentration of $2-4 \mu \mathrm{M}$ in $10 \mathrm{mM}$ Tris- $\mathrm{HCl}, \mathrm{pH} 7.5,10 \mathrm{mM} \mathrm{NaCl}$ buffer.

a)

Thermal Denaturation of Controls

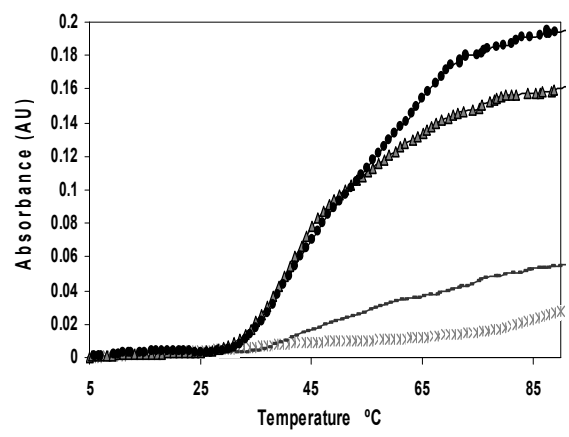

b)

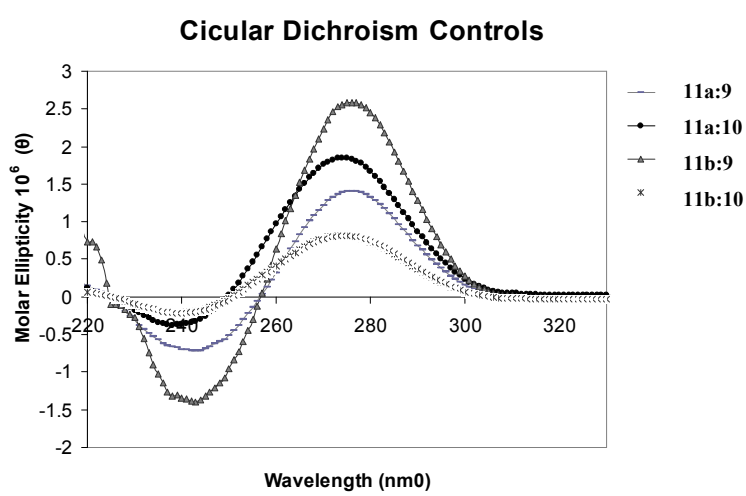

Figure S9. Control Studies a) Thermal Denaturation Experiments of control duplexes nicked 11a:9, 10 and ligated 11b:9, 10. b) Circular dichroism spectra of control duplexes nicked 11a:9, 10 and ligated 11b:9, 10. For all samples experiments were conducted in a concentration of 2-4 $\mu \mathrm{M}$ in $10 \mathrm{mM}$ Tris- $\mathrm{HCl}, \mathrm{pH} 7.5,10 \mathrm{mM} \mathrm{NaCl}$ buffer. 


\section{Characterization of parallel duplex formation between lariat precursors $1 b, 2 b$, and $8 b$ and}

\section{their target template strand.}

Duplexes were monitored by native polyacrylamide gel electrophoresis (Figure S8), a technique that resolves duplex from ssONs on the basis of their molecular mass when an electric current is applied. Upon electrophoresis ssONs and duplexes move at a rate that is inversely proportional to their molecular mass, larger molecules (duplexes) feeling more resistance and hence taking longer to move. Thus titrating a single strand oligonucleotide with its complementary strand should result in the formation of a slower moving (duplex) band. This can be readily seen for apDNA:RNA $(\mathbf{1 2}+\mathbf{1 0})$, apRNA:RNA $(\mathbf{1 4}+\mathbf{1 0})$, and pRNA:RNA $(\mathbf{1 5}+\mathbf{1 0})$, but not for the pDNA:RNA $(\mathbf{1 3}+\mathbf{1 0})$, consistent with the thermal denaturation results described above. That is no parallel DNA:RNA duplex forms from mixing 13 and $\mathbf{1 0 .}$

To further illustrate duplex formation, each hybrid resulting from the hybridization of ssON 12-15, and $\mathbf{1 b}$ in the presence of $\mathbf{1 0}$ was subjected to digestion by the E. coli RNase H1 enzyme. RNase H mediated cleavage results in the recognition of DNA/RNA hybrids of almost any sequence and cleavage of the RNA complement. ${ }^{2,3}$ As the substrate specificity of RNase $H$ towards parallel stranded DNA/RNA and RNA/RNA duplexes is not known, we decided to examine this issue on control sequences (13:10 and 15:10 respectively). This knowledge will then be used to probe/confirm parallel duplex formation in complexes such as pRNA/RNA 15:10. It is important to note the length of parallel base pairs resulting between ssON lariat precursors $\mathbf{1 b}, \mathbf{2 b}$ and $\mathbf{8 a}$ with $\mathbf{1 0}$. The DNA ssON $\mathbf{1 b}$ and $\mathbf{2 b}$ will form six antiparallel and five parallel base pairs, respectively, when associating with RNA template 10. Likewise, the ssON RNA lariat precursor $8 \mathbf{a}$ is involved in 8 (antiparallel) and 5 (parallel) base pair associations. RNase $\mathrm{H}$ cleaves the target RNA template 10, to give 5'-phosphate-3'-OH nucleotides, when hybridized to the target strands $\mathbf{1 2}, \mathbf{1 3}$, and $\mathbf{1 b}$ as indicated in Figure S9. This is quite evident in the native apDNA/RNA duplex 12:10 where complete cleavage is observed. An additional feature of the RNase H enzyme is that the RNA/RNA duplexes are not substrates for the RNase H enzyme. ${ }^{4}$ Thus, as expected, the negative control duplex, 14:10 is resistant to RNase H-mediated degradation. Both 
13:10 (pDNA/RNA hybrid) and 1b:10, (preorganized lariat ssON/RNA precursor) upon exposure to excess amounts of enzyme, resulted in cleavage to 8 mer and 6 mer species respectively (Figure S9). In the case of $\mathbf{1 b}$, the 6 mer cleavage product (greater than the parallel region) is the result of enzymatic digestion of 7 nucleotides of the 13 mer RNA template. This finding provides evidence for the existence of the preorganized (i.e. fully hybridized) form of the nicked DNA lariat because, in order for the enzyme to be active in the antiparallel region of $\mathbf{1 b : 1 0}$, there had to be duplex character through the entire ssON/template. Therefore, although we were unable to detect duplex formation of the parallel DNA/RNA nicked DNA lariat hybrids by thermal denaturation or gel-shift assays, the enzymatic analysis, carried out at $4{ }^{\circ} \mathrm{C}$, suggest complexation. Perhaps the melting temperatures of the 13:10 is too weak (ca. $0-5^{\circ} \mathrm{C}$ ) to be detected by such methods. ${ }^{5}$

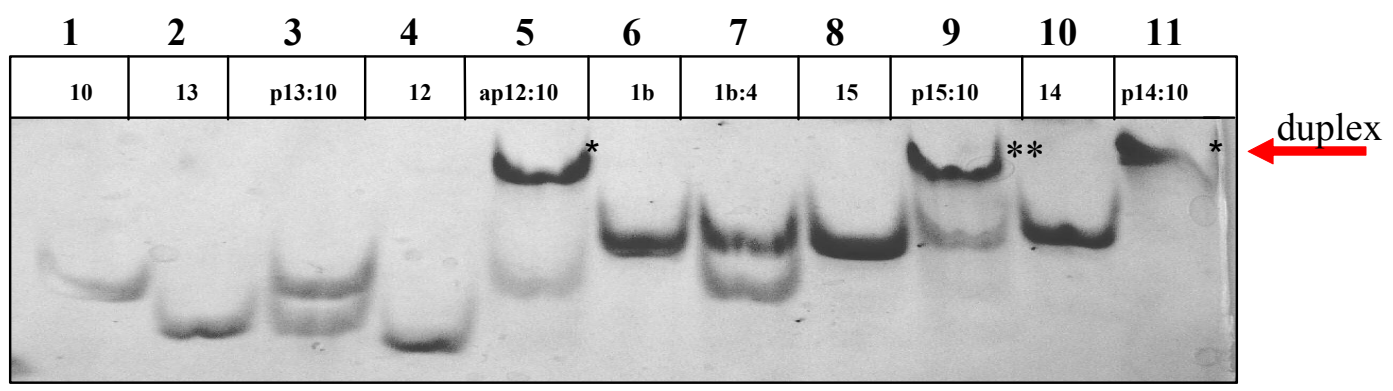

Figure S10. Nondenaturing (native) 20\% PAGE. Analysis of control duplexes containing antiparallel and parallel orientation. Duplex formation in the parallel and antiparallel orientation is indicated by $*$ and $* *$, respectively $\left(5^{\circ} \mathrm{C}\right)$. 


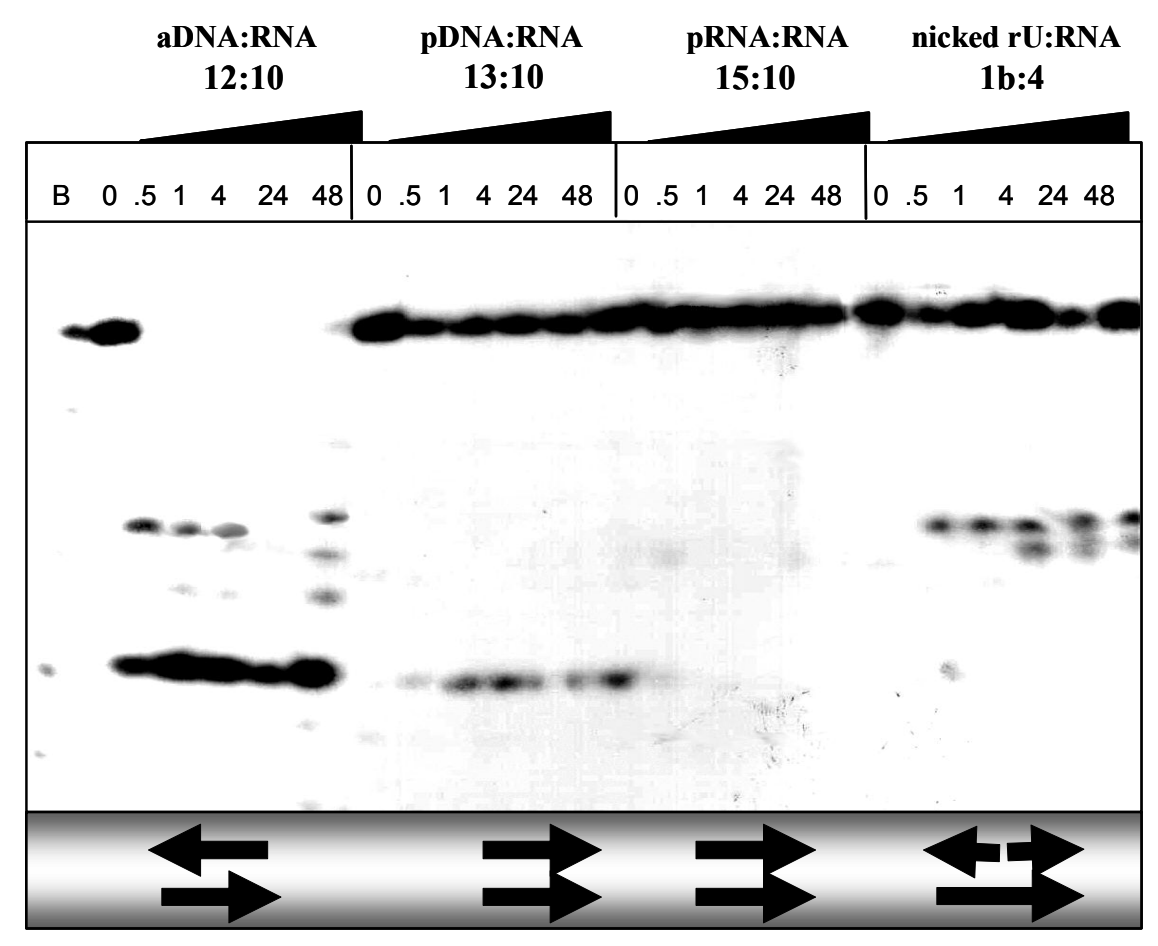

Figure S11. Parallel vs Antiparallel Duplexes: $12 \%$ PAGE E. coli RNase H1-directed cleavage patterns of duplexes. All assays were conducted in a final volume of $10 \mu \mathrm{L}$, each reaction involved the hybridization of 1 pmol of $5^{\prime}-\left[{ }^{32} \mathrm{P}\right]$-template RNA and 3 pmol of precursor oligonucleotide $(\mathbf{1 2}, \mathbf{1 3}, \mathbf{1 4}$, 15, 1b) in $60 \mathrm{mM}$ Tris- $\mathrm{HCl}(\mathrm{pH} 7.8$, containing $2 \mathrm{mM}$ dithiothreitol, $60 \mathrm{mM} \mathrm{KCl}$, and $10 \mathrm{mM} \mathrm{MgCl} 2$. Assays were carried out at $4{ }^{\circ} \mathrm{C}$ upon addition of RNase H. Assay was conducted with an excess of enzyme $1.0 \mu \mathrm{L} /$ reaction - stock $10 \mathrm{U} / \mathrm{ul}$. B: The base hydrolysis ladder of the template as a control. Note schematic arrow representation indicated polarity of duplexes. 


\section{References}

(1) (60) Distler, A. M.; Allison, J. Anal. Chem. 2001, 73, 5000-5003.

(2) Nishizaki, T.; Iwai, S.; Ohtsuka, E.; Nakamura, H. Biochemistry 1997, 36, 2577-2585.

(3) Uchiyama, Y.; Miura, Y. Inoue, H.; Ohtsuka, E. Ueno, Y.; Ikehara, M.; Iwai, S. J. Mol. Biol. 1994, $243,782-791$.

(4) Mangos, M. Ph.D.Thesis, McGill University, Montreal, QC, Canada, 1999.

(5) Note that moderate cleavage of 15:10, to the best of our knowledge is the first example of RNase H cleavage of a pRNA:RNA duplex. 